\title{
Features of polymorphism of calpastatin and somatotropin genes in young sheep, obtained from crossing ewes of Kalmyk fat-rumped sheeps and dorper rams
}

\author{
Vladimir Pogodaev ${ }^{1, *}$, Bator Aduchiev ${ }^{2}$, Lydia Kononova $^{1}$, Maya Aslanukova ${ }^{3}$ and Irina \\ Kardanova $^{3}$ \\ ${ }^{1}$ North Caucasian Federal Scientific Agrarian Center, 49, Nikonova str., 356241, Mikhailovsk, Russia \\ ${ }^{2}$ Kalmyk Research Institute of Agriculture named after M.B. Narmaev, 5, Avenue Gorodovikova, \\ 358001, Elista, Russia \\ ${ }^{3}$ North Caucasian State Acadeny, 36, Cherkessk, st., 369000, Stavropol, Russia
}

\begin{abstract}
The article presents the study of polymorphism of the CAST and $\mathrm{GH}$ genes, which determine the features of the manifestation of the productive and biological characteristics of sheep with $1 / 2$ Kalmyk $+1 / 2$ Dorper blood system. Calpastatin gene polymorphism represented by alleles $\mathrm{M}$ and $\mathrm{N}$, whose frequency was 0,65 and 0,35 ; genotypes $\mathrm{MM}, \mathrm{MN}$ - 30 and $70 \%$ accordingly. The desired NN genotype has not been identified. A relatively uniform incidence of allele $\mathrm{N}(0,35)$ CAST gene and $\mathrm{B}(0,40) \mathrm{GH}$ was established, what contributed to an almost equal distribution of allele frequencies $\mathrm{M}(0,65)$ and $\mathrm{A}(0,60)$ genes of calpastatin and somatotropin accordingly. The frequency of heterozygous genotypes occurrence by CAST gene composed 0,7. By GH gene the following distribution of genotype frequencies is observed. Frequency of occurrence homozygous $\mathrm{AA}$ and heterozygous $\mathrm{AB}$ genotypes was equal to and is 0,4 , wherein the frequency of occurrence advised homozygous $B B$ genotype was 0,2 . Among the animals studied, sheep with a complex genotype are most common $\mathrm{CAST}^{\mathrm{MN}} \mathrm{GH}^{\mathrm{AB}}(40 \%)$. The amount of percent $\mathrm{CAST}^{\mathrm{MM}} \mathrm{GH}^{\mathrm{AA}}$ and $\mathrm{CAST}^{\mathrm{MN}} \mathrm{GH}^{\mathrm{AA}}$ is in $22,2 \% .10 \%$ is for genotypes $\mathrm{CAST}^{\mathrm{MM}} \mathrm{GH}^{\mathrm{BB}}$ and $\mathrm{CAST}^{\mathrm{MN}} \mathrm{GH}^{\mathrm{BB}}$.
\end{abstract}

\section{Introduction}

Scientists and major producers are engaged in improving productive qualities using marker-associated selection, since this is the shortest and most promising way to increase the efficiency of livestock in all sectors: cattle breeding pig breeding, poultry breeding and sheep breeding is no exception [1-3].

In modern conditions of economic agricultural production development, the level of competitive sheep breeding ability is determined, mainly, by lamb production. Sheep farming is still an important, traditional livestock industry in Kalmykia. Given the fact that

\footnotetext{
*Corresponding author: pogodaev_1954@mail.ru
} 
until now in our country there exists a problem of animal protein population security meat, then role of sheep breeding in its solution increases significantly.

The priority vector in sheep breeding became the meat industry development. In recent years, there has been a steady increase in lamb production, ammount of specialized meat breeds is increasing [4-5]. Increased production and improved quality of lamb largely determined by introduction of new areas of use based on combination of classical selection methods with molecular genetics, DNA markers in particular, with the help of which significant results have been achieved in sheep breeding.

Currently, the proven connection establishment problem between meat productivity genetic markers and phenotypic traits still completely unresolved, because full manifestation of the animal organism genetic potential depends on a number of factors: both physiological and paratypical [6].

Today marker selection is the leading direction of practical genetics (Marker Assisted Selection - MAS), which involves the use of DNA markers, associated with high level of productivity, which is of significant practical importance for the development of Russian sheep breeding.

The use of new methods based on DNA technology, along with other innovations allows to make sheep farming modern industry competitive and cost-effective [7-8].

The practical significance of such studies lies in solving a number of applied selection problems, one of which is the identification of genetic markers, influencing the sheep meat productivity. In perspective, these studies will allow to identify evaluation criteria for predicting breeding animals' genetic potential. [9].

Promising genes whose allelic variants are associated with the phenotypic manifestation of economically important animal traits are considered as DNA markers, exactly the calpastatin gene (CAST), responsible for meat productivity and tenderness of sheep meat, growth hormone gene $(\mathrm{GH})$, which regulates growth and development.

If abroad the research boom can already be said to have passed, then in Russia calpastatin and somatotropin genes polymorphism is at the stage of study [10-11].

The nucleotide sequences of calpastatin gene were detected and established the connection between polymorphism gene CAST and sheep meat productivity indicators [1213].

Calpastatin considered as weight gaining and meat quality performance marker, since it encodes polypeptide, which determines tenderness of meat when ripening after slaughter [14-15].

Growth hormone gene (somatotropin, somatotropic hormone, GH) - one of the promising candidate genes, controlling protein synthesis. somatotropin - the main hypophysic hormone, has a wide range of biological effects and significantly affects all the body cells [16].

Somatotropic hormone coordinates and regulates the metabolic rate due to deposition of calcium and phosphorus in bones, thanks to it, anabolic processes are activated, accompanied by body size increase and skeletal growth stimulation [17-18]. It is one of the main animals' somatic growth regulators, since GH gene overexpression promotes accelerated growth and development of the body [19-21].

The aim of the work was to determine CAST and GH gene polymorphism and study of the alleles and genotypes frequency distribution in hybrid young sheep.

\section{Material and methods of the study}

DNA was the biological material for calpastatin and somatotropin genes polymorphism studying, picked out from young 10 cross-breed sheep blood samples ( $1 / 2$ Kalmyk $+1 / 2$ Dorper) using reagent kits Diatom ${ }^{\mathrm{TM}}$ DNA Prep 200 (IsoGeneLab, Russia). Genotyping 
studies were carried out in licensed laboratory of immunogenetics and DNA technologies of the North Caucasus Federal Scientific Agricultural Center (№ accreditation POCC RL /001/21PD29).

For carrying out PCR-RFLP (restriction fragment length polymorphism) the kits «GenPak ${ }^{\mathrm{R}}$ PCR Core» were applied, (IsoGeneLab, Moscow). Amplification of genes CAST and GH was carried out on a four-channel programmable thermal cycler "Tertsik" by "DNA-technology" company (Russia). Amplification of CAST gene fragment was carried out using oligonucleotide primers manufactured by Syntol LLC (Russia):

F: 5'-TGGGGCCCAATGACGCCATCGATG-3'.

R: 5'-GGTGGAGCAGCACTTCTGATCACC-3' in the next mode (pre denaturation at $95^{\circ} \mathrm{C}-4$ minutes; cycling -35 cycles: $94^{\circ} \mathrm{C}-45$ seconds, $62^{\circ} \mathrm{C}-45$ seconds, $72^{\circ} \mathrm{C}-45$ seconds; final synthesis at $72^{\circ} \mathrm{C}-7$ minutes).

The length of the amplified CAST gene fragment composed 622 nucleotide pairs. For restriction and amplified region calpastatin gene endonuclease was used MspI in accordance with manufacturer recommendations (SibEnzyme LLC). Genotype MM represented by fragments: 336 and 286 bps, NN genotype - 622 bps and MN genotype $622,336,286$ bps

Amplification of GH gene fragment was carried out using primers:

F: 5'-GGAGGCAGGAAGGGATGAA- 3'.

R: 5'-CCAAGGGAGGGAGAGACAGA-3' in the next mode (pre denaturation at $95^{\circ} \mathrm{C}$ -5 minutes; cycling -33 cycles: $95^{\circ} \mathrm{C}-45$ seconds, $60^{\circ} \mathrm{C}-45$ cseconds, $72^{\circ} \mathrm{C}-45$ seconds; final synthesis at $72^{\circ} \mathrm{C}-10$ minutes).

The length of amplified GH gene fragment made up 934 nucleotide pairs. Endonuclease was used to restrict the amplified region of the somatotropin gene HaeIII. The presence of 10 restriction sites corresponded to A allele, and the presence of 11 th site - to allele B.

Genotype AA represented by fragments: 277-, 202-, 110-, 100-, 94-, 68-, 49-, 22- , 8 and 4 bps; BB - 256-, 202-, 110-, 100-,94-, 68-, 49-, 22-, 21-, 8- and 4 bps and AB - 277-, 256-, 202-, 110-, 100-, 94-, 68-, 49-, 22- ,21-, 8- and 4 bps.

To conduct obtained data genetic-statistical analysis, the occurrence frequency of alleles and genotypes was calculated.

According to Hardy-Weinberg's law, the expected distribution of genotypes in the studied sample was calculated. The magnitude $\chi^{2}$ (pearson conformance criterion) determined by the formula:

$$
\chi^{2}=\sum \frac{\left(\mathrm{H}_{0}-\mathrm{H}_{\mathrm{E}}\right)^{2}}{\mathrm{H}_{\mathrm{E}}}
$$

where $\mathrm{H}_{0}$ - actually observed number of genotypes,

$\mathrm{H}_{\mathrm{E}}$ - theoretically expected number of genotypes.

\section{Results of the study}

Analysis of the results of crossbreeding young sheep genotyping ( $1 / 2$ Kalmyk $+1 / 2$ Dorper) is established, that calpastatin and samototropin gene polymorphism is represented by two alleles and three genotypes: CAST gene - by alleles $\mathrm{M}$ and $\mathrm{N}$, genotypes $\mathrm{MM}, \mathrm{MN}, \mathrm{NN}$; $\mathrm{GH}$ gene - by alleles $\mathrm{A}$ and $\mathrm{B}$, genotypes $\mathrm{AA}, \mathrm{AB}, \mathrm{BB}$ with different frequency of occurrence, which is presented in the table 1 . 
Table 1. Frequency of occurrence of calpastatin and samototropin alleles and genotypes in young sheep crossbreeds ( $1 / 2$ Kalmyk fat tail $+1 / 2$ Dorper $)$.

\begin{tabular}{|l|c|c|c|c|c|}
\hline $\begin{array}{l}\text { Calpastin (CAST) } \\
\text { genotype/allele }\end{array}$ & $\mathrm{MM}$ & $\mathrm{MN}$ & $\mathrm{NN}$ & $\mathrm{M}$ & $\mathrm{N}$ \\
\hline Frequency of occurrence & 0.3 & 0.7 & - & 0.65 & 0.35 \\
\hline $\begin{array}{l}\text { Growth hormon }(\mathrm{GH}) \\
\text { genotype/allele }\end{array}$ & $\mathrm{AA}$ & $\mathrm{AB}$ & $\mathrm{BB}$ & $\mathrm{A}$ & $\mathrm{B}$ \\
\hline Frequency of occurrence & 0.4 & 0.4 & 0.2 & 0.6 & 0.4 \\
\hline
\end{tabular}

A relatively identical $\mathrm{N}(0,35)$ gene CAST and B $(0,40)$ GH allele frequency was established, what contributed to almost equal frequency occurrences distribution of alleles $\mathrm{M}(0,65)$ and $\mathrm{A}(0,60)$ of calpastatin and samototropin genes, respectively.

Significant differences were revealed in the frequency occurrences distribution of homozygous and heterozygous genotypes in the calpastatin and somatotropin genes. The desired genotype NN by calpastine gene in the analyzed sample of animals was not found. The frequency of homozygous genotype MM composed 0,3 , and heterozygous genotype MN by CAST gene $-0,7$.

A slightly different distribution of genotype frequencies by GH gene is observed. Frequency of occurrence of homozygous $\mathrm{AA}$ and heterozygous $\mathrm{AB}$ genotypes was equal and composed 0,4 , wherein frequency of occurrence of desired homozygous genotype $\mathrm{BB}$ composed 0,2 .

Value of $\chi^{2}$ depends on the number of degrees of freedom (table 2).

Table 2. Pearson criterion values, $\chi^{2}$ by CAST and GH genes.

\begin{tabular}{|c|c|c|c|c|c|c|}
\hline \multicolumn{2}{|c|}{$\begin{array}{c}\text { Actually observed distribution of } \\
\text { genotypes }\end{array}$} & \multicolumn{2}{c|}{$\begin{array}{c}\text { The theoretically expected } \\
\text { distribution of genotypes }\end{array}$} & \multirow{2}{*}{$\begin{array}{c}\text { Pearson } \\
\text { criterion, } \boldsymbol{\chi}^{\mathbf{2}}\end{array}$} \\
\hline \multicolumn{7}{|c|}{ Calpastatin (CAST) } \\
\hline MM & NN & MN & MM & NN & MN & \multirow{2}{*}{2.90} \\
\hline 3 & 0 & 7 & 4.2 & 1.2 & 4.6 & \\
\hline \multicolumn{7}{|c|}{ Growth gormon (GH) } \\
\hline AA & BB & AB & AA & BB & AB & \multirow{2}{*}{0.27} \\
\hline 4 & 2 & 4 & 3.6 & 1.6 & 4.8 & \\
\hline
\end{tabular}

Criterion calculation $\chi^{2}$ was carried out at significance level $P \geq 0,99$. Value of $\chi^{2}$ for this sample amounted to 2,90 by calpastine gene and 0,27 - by growth hormon, which is much less, than standard value $\chi^{2}=9,2$ at a given significance level. Therefore, the gene balance in these samples is not disturbed.

Using the Pennet Grid, of nine theoretically possible complex genotypes, experimental animals were identified five (table 3 ).

Table 3. Frequency distribution of complex genotypes.

\begin{tabular}{|c|c|c|}
\hline Complex genotypes & Livestock & Frequency of occurrence, $\%$ \\
\hline $\mathrm{CAST}^{\mathrm{NN}} \mathrm{GH}^{\mathrm{BB}}$ & - & - \\
\hline $\mathrm{CAST}^{\mathrm{NN}} \mathrm{GH}^{\mathrm{AB}}$ & - & - \\
\hline $\mathrm{CAST}^{\mathrm{NN}} \mathrm{GH}^{\mathrm{AA}}$ & - & - \\
\hline $\mathrm{CAST}^{\mathrm{MM}} \mathrm{GH}^{\mathrm{BB}}$ & 1 & 10 \\
\hline $\mathrm{CAST}^{\mathrm{MM}} \mathrm{GH}^{\mathrm{AB}}$ & - & - \\
\hline $\mathrm{CAST}^{\mathrm{MM}} \mathrm{GH}^{\mathrm{AA}}$ & 2 & 20 \\
\hline $\mathrm{CAST}^{\mathrm{MN}} \mathrm{GH}^{\mathrm{BB}}$ & 1 & 10 \\
\hline $\mathrm{CAST}^{\mathrm{MN}} \mathrm{GH}^{\mathrm{AB}}$ & 4 & 40 \\
\hline $\mathrm{CAST}^{\mathrm{MN}} \mathrm{GH}^{\mathrm{AA}}$ & 2 & 20 \\
\hline
\end{tabular}


Animals having the desired complex genotype including combinations ща 4 marker alleles $\mathrm{CAST}^{\mathrm{NN}} \mathrm{GH}^{\mathrm{BB}}$, two genes were not identified. В исследуемой выборке отсутствуют животные с генотипами $\mathrm{CAST}^{\mathrm{NN}} \mathrm{GH}^{\mathrm{AB}}, \mathrm{CAST}^{\mathrm{NN}} \mathrm{GH}^{\mathrm{AA}}, \mathrm{CAST}^{\mathrm{MM}} \mathrm{GH}^{\mathrm{AB}}$. Genotyping analysis indicates, that the most common animals are with $\mathrm{CAST}^{\mathrm{MN}} \mathrm{GH}^{\mathrm{AB}}$ complex genotype $(40 \%) .22,2 \%$ accounts for animals, having $\mathrm{CAST}^{\mathrm{MM}} \mathrm{GH}^{\mathrm{AA}}, \mathrm{CAST}^{\mathrm{MN}}$ $\mathrm{GH}^{\mathrm{AA}}$ genotypes and $10 \%$ having $\mathrm{CAST}^{\mathrm{MM}} \mathrm{GH}^{\mathrm{BB}}$ and $\mathrm{CAST}^{\mathrm{MN}} \mathrm{GH}^{\mathrm{BB}}$.

\section{Conclusion}

The polymorphism of the calpastatin and somatotropin genes in the studied sample of animals was determined. Calpastatin gene polymorphism represented by alleles $\mathrm{M}$ and $\mathrm{N}$ with frequency 0,65 and 0,35 . The desired genotype $\mathrm{NN}$ was not identidied, frequency of MM, MN genotype - 0,3 and 0,7 accordingly. Somatotropin gene polymorphism represented by alleles $\mathrm{A}$ and $\mathrm{B}$ with frequency 0,60 and 0,40 . Genotypes $\mathrm{AA}, \mathrm{BB}$ and $\mathrm{AB}$ founded with frequency 0,$4 ; 0,2$ and 0,4 accordingly.

Thus, genotyping analysis results indicates, that in the studied sample of animals, having the desired complex genotype, including combinations of 4 marker alleles CAST ${ }^{\mathrm{NN}}$ $\mathrm{GH}^{\mathrm{BB}}$, was not identified. In crossbreed young sheep ( $1 / 2$ Kalmyk $+1 / 2$ Dorper) there were no animals of the desired NN genotype by calpastatin gene, but wherein the proportion of heterozygous $\mathrm{MN}$ individuals composed $70 \%$. According to growth hormone, the number of desired $\mathrm{BB}$ genotypes composed $20 \%$ and heterozygotes $\mathrm{AB}-40 \%$.

The obtained data can be considered as studying population genetic characteristics and based on its draw a preliminary conclusion about received crossbreeding genetic identity $(1 / 2$ Kalmyk $+1 / 2$ Dorper). Regular screening to identify desired genotypes would make it possible to adjust the change in certain alleles and genotypes frequency of occurrence in a particular group, flock, populations, by targeted selection and picking pairs for selection.

\section{References}

1. E.C. Webb, N.H. Casey, Livestock Science 130, 33-40 (2010) https://doi.org/10.1016/j.livsci.2010.02.008

2. M. Aali, H. Moradi-Shahrbabak, M. Moradi-Shahrbabak, M. Sadeghi, A. Reza Yousefi, Small Ruminant Research 149, 40-51 (2017) https://doi.org/10.1016/j.smallrumres.2016.12.026

3. K.F. Mahrous, M.S. Hassanane, H.I. Shafey, M. Abdel Mordy, H.E. Rushdi, Journal of Genetic Engineering and Biotechnology 14(2), 233-240 (2016) https://doi.org/10.1016/j.jgeb.2016.09.003

4. V. Pogodaev, N. Sergeeva, V. Marchenko, XII International Scientific Conference on Agricultural Machinery Industry IOP Conf. Series: Earth and Environmental Science 403 (2019) doi:10.1088/1755-1315/403/1/012114

5. C. Kazumi Kiya, V. Breno Pedrosa, K. Felipe Avelar Muniz, A. Lopes Gusmão, L. Fernando Batista Pinto, Small Ruminant Research 171, 57-62 (2019) https://doi.org/10.1016/j.smallrumres.2018.12.007

6. M. Greguła-Kania, T.M. Gruszecki, A. Junkuszew, E. Juszczuk-Kubiak, M. Florek, Meat Science 154, 69-74 (2019) https://doi.org/10.1016/j.meatsci.2019.04.007

7. V. Pogodaev, B. Aduchiev, N. Sergeeva, XII International Scientific Conference on Agricultural Machinery Industry IOP Conf. Series: Earth and Environmental Science 403 (2019) doi:10.1088/1755-1315/403/1/012111 
8. I.F. Gorlov, N.V. Shirokova, A.V. Randelin, V.N. Voronkova, N.I. Mosolova, E.Y. Zlobina, Y.A. Kolosov, N.F. Bakoev, M.A. Leonova, S.Y. Bakoev, A.Y. Kolosov, L.V. Getmantseva, Turkish Journal of Veterinary and Animal Sciences 40(4), 399-405 (2016)

9. M. Aali, M. Moradi-Shahrbabak, H. Moradi-Shahrbabak, M. Sadeghi, Gene 537(1), 132-139 (2014) https://doi.org/10.1016/j.gene.2013.12.023

10. M.A. Azari et.al., Slovak Journal of Animal Science 45(1), 111-116 (2012)

11. R. Bakhtiar, A. Abdolmohammadi, H. Hajarian, Z. Nikousefat, D. KalantarNeyestanaki, Food and Biotechnological Engineering 11(7), 506-509 (2017)

12. M. Kolenda, E. Grochowska, S. Milewski, S. Mroczkowski, Small Ruminant Research 177, 29-35 (2019) https://doi.org/10.1016/j.smallrumres.2019.06.007

13. S. Gharahveysi, African Journal of Biotechnology 11(13), 344-352 (2012)

14. M. Suleman et.al., African Journal of Biotechnology 4(47), 641-650 (2012)

15. C. Kazumi Kiya, V. Breno Pedrosa, K. Felipe Avelar Muniz, A. Lopes Gusmão, L. Fernando Pinto Batista, Small Ruminant Research 177, 141-145 (2019) https://doi.org/10.1016/j.smallrumres.2019.06.015

16. R. Deb, C. Sekhar Mukhopadhyay, G. Singh Sengar, and others, Poultry, and Fisheries, Academic Press 4, 107-129 (2020) https://doi.org/10.1016/B978-0-12-8163528.00004-7

17. R.D. Warner, P.L. Greenwood, D.W. Pethick, D.M. Ferguson, Meat Science 86(1), 171183 (2010) https://doi.org/10.1016/j.meatsci.2010.04.042

18. I.F. Gorlov, N.V. Shirokova, M.I. Slozhenkina, N.I. Mosolova, E.Y. Zlobina, Y.A. Kolosov, L.V. Getmantseva, N.F. Bakoev, M.A. Leonova, A.Y. Kolosov, Small Ruminant Research 150, 11-14 (2017)

19. A. Hajihosseinlo, S. Jafari, M. Ajdary, Adv. Biomed. Res. 4, 172-181 (2015)

20. D.A. Souza, A.B. Selaive-Villarroel, E.S. Pereira, E.M.C. Silva, R.L. Oliveira, Small Ruminant $\quad$ Research $\quad 145, \quad 76-80 \quad$ (2016) https://doi.org/10.1016/j.smallrumres.2016.10.017

21. E. Armstrong, G. Ciappesoni, W. Iriarte, C. Da Silva, F. Macedo, E.A. Navajas, G. Brito, R. San Julián, D. Gimeno, A. Postiglioni, Meat Science 145, 202-208 (2018) https://doi.org/10.1016/j.meatsci.2018.06.014 